Article

EL-NAKHLAWY, F.S. ${ }^{1}$ AL-SHAREEF, A.R. ${ }^{1}$ IHSAN, M.Z..$^{*}$

\section{Assessment of Jeddah PaRks HealTh Status By Cyperus rotundus AND SOIL ANALYSIS UNDER WASTE WATER IRRIGATION}

\section{Avaliação do Estado de Saúde dos Parques de Jeddah por Meio de Análise de Cyperus rotundus e de Solo Irrigado com Efluentes}

\begin{abstract}
To investigate the health status of public parks in Jeddah city, a field survey was conducted based on the Cyperus rotundus weed and soil analysis of wastewater-irrigated parks during 2012. The city was divided into five different locations (North, South, East, West and Middle) and five parks were randomly sampled from each location; thus, the total number of sampled parks were twenty five. Toxic metals concentration were analyzed in the soil and in the plants while bacterial count was determined from the weed leaves. All studied toxic metals have significantly crossed the European Union safety limits for plant samples, while soil samples were just beyond the limit. The highest concentration was perceived for Lead (133-232 $\mathrm{m} \mathrm{kg}^{-1}$ ) and was followed by Chromium (80-141 $\mathrm{mg} \mathrm{kg}^{-1}$ ). The microbial analysis of one gram leaf sample of $C$. rotundus demonstrated a maximum bacterial count of 45,955 $\mathrm{cfu} \mathrm{g}^{-1}$, number of total E. coli form 34 and fecal coli form 8.65 at South and East Jeddah locations. These locations have also produced the highest concentration of toxic metals for both plant and soil samples. In crux, C. rotundus weeds may serve as an indicator of parks health by toxic metals and bacterial analysis that may infect the visitors, especially children's playing on it.
\end{abstract}

Keywords: Cyperus rotundus, chromium, bacteria, parks health, waste water irrigation.

RESUMO - Para investigar o estado de conservação de parques públicos na cidade de Jeddah, foi realizada uma pesquisa de campo com base na planta daninha Cyperus rotundus e na análise do solo dos parques irrigados com efluentes, em 2012. A cidade foi dividida em cinco locais diferentes (norte, sul, leste, oeste e centro), e cinco parques foram amostrados aleatoriamente a partir de cada local, gerando um número total de 25 parques. A concentração de metais tóxicos foi analisada no solo e na planta, enquanto a contagem bacteriana foi determinada a partir das folhas da planta daninha. Todos os metais tóxicos estudados ultrapassaram significativamente os limites de segurança da União Europeia para amostras de plantas, ao passo que as amostras de solo estavam apenas um pouco além do limite. A concentração mais elevada foi observada para o chumbo (133-232 $\mathrm{mg} \mathrm{kg}^{1}$ ), seguido do crômio (80-141 $\mathrm{mg} \mathrm{kg}^{-1}$ ). A análise microbiológica da amostra de um grama de folha de $\boldsymbol{C}$. rotundus demonstrou uma contagem bacteriana máxima de 45.955 ufc $\mathrm{g}^{-1}$, número de coliformes totais de $\boldsymbol{E}$. coli igual a 34 e número de coliformes fecais igual a 8,65, nos locais sul e leste do Parque Jeddah. Esses locais também produziram a maior concentração de metais tóxicos tanto para as amostras de plantas quanto para as do solo. Em resumo, as plantas daninhas $\boldsymbol{C}$. rotundus podem servir como um indicador do estado de conservação
Received: March 13, 2016

Approved: May 9, 2016

Planta Daninha 2017; v35:e017161097

1 King Abdulaziz University, Jeddah, Saudia Arabia. ${ }^{2}$ The Islamia University of Bahawalpur, Pakistan. 
de parques por meio da análise de metais tóxicos e bactérias que possam infectar os visitantes, especialmente crianças em atividades lúdicas.

Palavras-chave: Cyperus rotundus, cromo, bactérias, saúde de parques, irrigação com efluentes.

\section{INTRODUCTION}

Jeddah is the second largest city of Saudi Arabia with multicultural inhabitants. The city lacks vegetation due to arid land features of the region. However, it has 540 small recreational parks (Khan, 2015). The city falls under severe arid land conditions with limited fresh water resources. Irrigation for these parks is supplied by treated sewage water and industrial waste water (Alabdula'aly, 1997). There are 33 wastewater treatment plants with a capacity of 748 million cubic meters per year, and 15 more are under construction. Much of the treated wastewater is being reused for water green spaces in the cities (landscaping), for irrigation in agriculture and other uses (Alabdula'aly, 1997). Health issues (diarrhea, cramps, nausea or vomiting) have been reported by frequent visitors to these parks. Previously, heavy metals built up in soil and plants have been documented in field crops when irrigated with waste water (Muchuweti et al., 2006; Singh et al., 2010).

Plants have tremendous potential for growth in waste water and accumulate toxic metals into their foliage (Demirezen and Aksoy, 2006). This accumulation is directly proportional to the concentration of heavy metals in the irrigation waste water, irrigation frequency and duration (Rusan et al., 2007). Long term exposure to toxic waste irrigation resulted in higher accumulation of toxic metals that becomes dangerous to visitors' health, especially children's (Ogwuegbu and Muhanga, 2005). Polluted irrigation has also documented significant presence of infectious bacteria that caused severe health issues (Zhang et al., 2008).

Nut grass (Cyperus rotundus) covers the major area of most of the parks as a wild plant. This weed grows abundantly under waste water irrigation as compared to Bermuda grass (Cynodon dactylon) that is used as artificially planted turf. Cyperus rotundus is fast-growing and classified as $\mathrm{C} 4$, which makes it suitable to moist, dry, saline and waste land areas. C. rotundus is also very common worldwide, especially in South East Asia, competing against 52 different crops in 92 countries in the tropical and subtropical regions of the world (Rao, 2000). Leaf pattern/symmetry and stem structure make it unique compared with other grasses, as it has narrow linear folded leaves with simple leaf blade without any collar along with a solid triangular stem. Tubers are the primary means of propagation for C. rotundus. The reproductive stage starts with lower temperatures in the winter. High herbicide resistance, fast and intensive vegetative growth and resprouting capability make it a more dangerous weed for most field crops and recreational parks. Sprinkler irrigation is mostly used to irrigate these parks. This may cause infection in the plant canopy as water drops of fall on the upper surface of leaves. Over the years, numerous health issues were reported in visitors to these parks. The problem was more serious in infants and children aged under ten, who usually play on grassy grounds in these parks. It is hypothesized that waste water irrigation may be the agent responsible for these health issues. Repeated irrigation with this polluted water may have resulted in huge accumulation of heavy metals in these parks. It is further postulated that this buildup of toxic metals has increased the chances of presence of infectious bacteria in soil and plants of these parks. Thus, the present experiment was planned to investigate the waste water irrigation effect on the level of the toxic metals and bacteria buildup in Cyperus rotundus weed plants and soil of these parks.

\section{MATERIALS AND METHODS}

Jeddah contains a total number of 540 parks scattered all over the city (Khan, 2015). The whole city was divided into five sections (North, South, East, West and Middle) for soil and plant sampling. From each location, five random parks were selected and a total of twenty five parks were sampled in the entire city. A simple randomized complete block design was use to choose five different parks. Four random samples were taken from each park for soil (up to $10 \mathrm{~cm}$ layer) and Cyperus rotundus plants (three different leaves from each plant). Each sample was classified 
into 2 subsamples, one for determination of toxic heavy metals and one for count of infectious bacteria.

Four toxic metals - Cadmium, Nickel, Lead, and Chromium - were analyzed in the soil and C. rotundus plant samples by using Inductively Coupled Plasma Atomic Emission Spectrometry (ICP-AES). Count of total bacteria, number of total $E$. coli forms and number of fecal coli form were determined in each subsample of plants according to APHA (2005). LB Miller broth medium was used for E. coli growth and propagation. Ready availability, simple composition and fast growth rate were some benefits associated with the selection of this medium. The presence of $E$. coli in water is a strong indication of sewage water contamination. Sewage may contain many types of disease-causing organisms, but $\mathrm{E}$. coli is the most common form. These toxic metals and bacterial form were analyzed, due to higher health risks associated with their presence.

\section{Statistical Analysis}

The collected data were subjected to the analysis of variance technique after applying the analysis of variance assumptions. The revised least significant difference (RLSD) test was employed to test the level of significance of the treatments' mean at $P \leq 0.05$ (El-Nakhlawy, 2010). The statistical analysis was performed by using the statistical software SAS 9.2.

\section{RESULTS AND DISCUSSION}

\section{Cyperus rotundus}

The C. rotundus reported accumulation of all the studied toxic metals in their foliage; however, their concentration was variable, depending upon the sampling location and the studied metal (Table 1). The concentration of lead was significantly higher $\left(133 \mathrm{mg} \mathrm{kg}^{-1}\right)$ among all studied metals in the south of the city; however, the east reported maximum presence of chromium $\left(80 \mathrm{mg} \mathrm{kg}^{-1}\right)$, cadmium (69 $\left.\mathrm{mg} \mathrm{kg}^{-1}\right)$ and nickel $\left(26 \mathrm{mg} \mathrm{kg}^{-1}\right)$. All these heavy metals have crossed the European safety limits for all locations except for the western part for cadmium and the northern part for cadmium, chromium and nickel. The middle and eastern parts presented maximum contamination while chromium and lead showed the highest toxicity level. The northern parks showed the least accumulation of these toxic metals; however, it has also crossed the European safety limits for lead accumulation.

\section{Soil}

Soil analysis for toxic metals accumulation presented inconstant results for all the studied sites. Lead storage had the maximum value $\left(232 \mathrm{mg} \mathrm{kg}^{-1}\right)$ as compared to other studied toxic metals, and it followed the same trend for different locations as observed for plant samples (Table 2). The soil toxicity level of parks was also variable for different locations viz., West Jeddah reported the maximum concentration of chromium and South Jeddah presented maximum

Table 1 - Means of toxic metal concentration in the Cyperus rotundus plants grown in Jeddah parks

\begin{tabular}{|l|c|c|c|c|}
\hline \multirow{2}{*}{ Location } & \multicolumn{4}{c|}{ Concentration $\left(\mathrm{mg} \mathrm{kg}^{-1}\right)$} \\
\cline { 2 - 5 } & Lead & Nickel & Chromium & Cadmium \\
\hline North Jeddah & $43.58 \mathrm{~d}$ & $9.76 \mathrm{~b}$ & $17.36 \mathrm{~d}$ & $8.93 \mathrm{c}$ \\
\hline South Jeddah & $132.75 \mathrm{a}$ & $10.37 \mathrm{~b}$ & $69.58 \mathrm{~b}$ & $41.58 \mathrm{~b}$ \\
\hline East Jeddah & $93.94 \mathrm{c}$ & $25.94 \mathrm{a}$ & $80.32 \mathrm{a}$ & $68.57 \mathrm{a}$ \\
\hline West Jeddah & $88.04 \mathrm{c}$ & $10.18 \mathrm{~b}$ & $33.45 \mathrm{c}$ & $3.58 \mathrm{~d}$ \\
\hline Middle Jeddah & $120.48 \mathrm{~b}$ & $24.16 \mathrm{a}$ & $78.51 \mathrm{a}$ & $42.40 \mathrm{~b}$ \\
\hline RLSD $(p \leq 0.05)$ & $* *$ & $*$ & $*$ & $* *$ \\
\hline Safety limit in plants ${ }^{(1)}$ & 30 & 10 & 30 & 30 \\
\hline
\end{tabular}

(1) EU (2002). Means followed by the same letter are not significant according to RLSD. * significant at $\mathrm{P} \leq 0.05$, and ** significant at $\mathrm{P} \leq 0.01$, 
Table 2 - Means of toxic metal concentration in the soil of Jeddah parks

\begin{tabular}{|l|c|c|c|c|}
\hline \multirow{2}{*}{ Location } & \multicolumn{4}{c|}{ Concentration $\left(\mathrm{mg} \mathrm{kg}^{-1}\right)$} \\
\cline { 2 - 5 } & Lead & Nickel & Chromium & Cadmium \\
\hline North Jeddah & $203.83 \mathrm{~b}$ & $15.14 \mathrm{~cd}$ & $117.71 \mathrm{~b}$ & $22.33 \mathrm{e}$ \\
\hline South Jeddah & $231.94 \mathrm{a}$ & $17.97 \mathrm{a}$ & $122.19 \mathrm{~b}$ & $98.90 \mathrm{a}$ \\
\hline East Jeddah & $172.99 \mathrm{c}$ & $15.95 \mathrm{bc}$ & $93.52 \mathrm{c}$ & $81.37 \mathrm{~b}$ \\
\hline West Jeddah & $130.14 \mathrm{~d}$ & $14.32 \mathrm{~d}$ & $141.15 \mathrm{a}$ & $67.72 \mathrm{c}$ \\
\hline Middle Jeddah & $112.61 \mathrm{~d}$ & $16.86 \mathrm{ab}$ & $120.80 \mathrm{~b}$ & $57.17 \mathrm{~d}$ \\
\hline RLSD $(p \leq 0.05)$ & $* *$ & $*$ & $* *$ & $*$ \\
\hline Safety limit in plants ${ }^{(1)}$ & 300 & 75 & 150 & 30 \\
\hline
\end{tabular}

(1) EU (2002). Means followed by the same letter are not significant according to RLSD. * significant at P $\leq 0.05$, and ** significant at $\mathrm{P} \leq 0.01$.

concentration of cadmium and lead. Data further illustrated that park soils has crossed the European safety limit for cadmium and nearly crossed it for chromium and lead. The lowest presence of these toxic metals was documented for North Jeddah, which presented lower values over European safety limits. Moreover, the average concentration of nickel $\left(16 \mathrm{mg} \mathrm{kg}^{-1}\right)$ in soil is well behind the EU safety limit $\left(75 \mathrm{mg} \mathrm{kg}^{-1}\right)$. The higher accumulation of lead and cadmium may be due to the higher concentration of these toxic metals in the irrigation source. Industrial waste mostly contains a higher amount of these toxic metals. Dikinya and Areola (2010) documented greater lead buildup in plant foliage under sewage water irrigation. Metals followed the accumulation trend of $\mathrm{Pb}>\mathrm{Ni}>\mathrm{Cr}>\mathrm{Cu}>\mathrm{Cd}$ in wheat grown in soils amended with sludge at 0, 10, 20 and 30\% of soil dry weight. Sandalio et al. (2001) reported differential accumulation of micronutrients with the presence of $0-50 \mu \mathrm{M} \mathrm{Cd}$ as $\mathrm{CdCI}_{2}$ in nutrient solution. There were harmful effects on child development or behavior in populations exposed to cadmium, nickel and chromium. Other effects may include pulmonary irritation, kidney dysfunction, bone demineralization and lung cancer (Bernard, 2008).

\section{Bacterial contamination}

Fresh plant samples analysis reported the contamination of all parks with different bacteria, especially the dangerous fecal coli (Table 3). Total bacterial count was maximum for South Jeddah; however, it was non-significant for all other sampling sites. Total number of coli forms $\left(34 \mathrm{~g} \mathrm{~g}^{-1}\right)$ and number of fecal coli $\left(8.65 \mathrm{~g}^{-1}\right)$ forms were also the highest in South Jeddah. Nevertheless, it was non-significant for the eastern part and significant for the north, west and middle parts. The direct relation between these bacterial count and fecal coli forms were investigated with the concentration of the studied toxic heavy metals. The highest count of these bacteria was recorded in South Jeddah, where the concentration of these toxic metals was also maximum in soil. However, the second highest count of these unsafe fecal coli was screened in East Jeddah, where the concentration of studied toxic metals was higher in plant samples.

Table 3 - Means of the total bacteria count, number of total coli forms and number of fecal coli form bacteria on Cyprus rotundus plants grown in the park soils

\begin{tabular}{|l|c|c|c|}
\hline \multirow{2}{*}{ Location } & \multicolumn{3}{|c|}{ Number $\left(\mathrm{g}^{-1}\right)$ fresh weight } \\
\cline { 2 - 4 } & Number of fecal coli form & Number of total coli form & Total bacteria count \\
\hline North Jeddah & $3.11 \mathrm{c}$ & $23.78 \mathrm{c}$ & $39854 \mathrm{a}$ \\
\hline South Jeddah & $8.65 \mathrm{a}$ & $33.93 \mathrm{a}$ & $45955 \mathrm{a}$ \\
\hline East Jeddah & $7.43 \mathrm{a}$ & $31.17 \mathrm{ab}$ & $45663 \mathrm{a}$ \\
\hline West Jeddah & $5.94 \mathrm{~b}$ & $24.95 \mathrm{c}$ & $40119 \mathrm{a}$ \\
\hline Middle Jeddah & $4.75 \mathrm{~b}$ & $26.09 \mathrm{bc}$ & $43757 \mathrm{a}$ \\
\hline RLSD $(p \leq 0.05)$ & $*$ & $*$ & $\mathrm{NS}$ \\
\hline
\end{tabular}

Means followed by the same letter are not significant according to RLSD. * significant at $\mathrm{P} \leq 0.05$, ** significant at $\mathrm{P} \leq 0.01$, and NS nonsignificant. 
It is clear that the irrigation with industrial waste has resulted in toxic metal accumulation in soils and plants that may have taken up and translocated the metals to their foliage. Differential uptake of these toxic metals may be attributed to their synergistic or antagonistic effects, depending upon their concentration in soil solution (Kabata-Pendias and Pendias 2001). Heavy metal solubility, mobility and availability in soils are controlled by reactions between metals and soil constituents which depend upon level of contamination, origin and metal speciation and physicochemical properties of soils (Harter and Naidu, 1995). Moreover, the concentration of these toxic metals in plant and soil showed a direct relation with screened infectious bacteria. These results indicated that the recently reported health issues might be due to the dangerous effects of children and infants using these parks or eating and playing on the landscape of these parks (Rusan et al., 2007; Zhang et al., 2008). Presence of these toxic metals and infectious bacteria has raised public health concerns. Mixing of these infectious bacteria in soil and plant has also raised serious doubt on the use of waste water as a source of irrigation in these parks.

In conclusion, all Jeddah parks were contaminated with E. coli and fecal coli bacteria, and also polluted with toxic heavy metals. Such pollution and contamination are very dangerous for the health of park visitors. Moreover, weed plants can be used as an indicator for determining the pollution level of parks, especially under waste water irrigation. It is therefore advisable to analyze, for toxicity and contamination status, the treated waste water that is used to irrigate city parks for the health safety issues of the visitors of these parks.

\section{REFERENCES}

Alabdula'aly A.I. Fluoride content in drinking water supplies of Riyadh, Saudi Arabia, Environ Monit Assess. 1997;48:261-272.

American public Health Association - APHA. Standard methods for the examination of water and waste water. Washington, DC: American Public Health Association, 2005.

Bernard A. Cadmium \& its adverse effects on human health. Indian J Med Res. 2008;128:557.

Demirezen D., Aksoy A. Heavy metal levels in vegetables in Turkey are within safe limits for Cu, $\mathrm{Zn}, \mathrm{Ni}$ and exceeded for $\mathrm{Cd}$ and Pb. J Food Qual. 2006;29:252-65.

Dikinya O., Areola O. Comparative analysis of heavy metal concentration in secondary treated wastewater irrigated soils cultivated by different crops. Int J Environ Sci Technol. 2010;7:337-46.

El-Nakhlawy F.S. Experimental design and analysis in scientific research. Saudi Arabia: Sci. Pub. Center, King Abdulaziz University, 2010.

EU. European Commission DG ENV. E3. Heavy Metals in Waste, Final Report Project. 2002. ENV.E.3/ETU/2000/0058http:// ec.europa.eu/environment/waste/studies/pdf/heavy_metalsreport.pdf.

Harter R.D., Naidu R. Role of metalorganic complexation in metal sorption by soils. Adv Agr. 1995;5:219-63.

Kabata-Pendias A., Pendias H. Trace elements in soils and plants. Boca Raton: CRC Press, 2001.

Khan F. Over 60,000 trees planted during Jeddah campaign. 2015. http://www.arabnews.com/saudi-arabia/news/715281

Muchuweti M.J. Heavy metal content of vegetables irrigated with mixtures of wastewater and sewage sludge in Zimbabwe: implications for human health. Agric Ecosyst Environ. 2006;112:41-8.

Naeem M. et al. Trianthema portulacastrum and Cyperus rotundus interference in maize and application of allelopathic crop extracts for their effective management. Planta Daninha. 2016; 34:209-18.

Ogwuegbu M.W., Muhanga W. Investigation of lead concentration in the blood of people in the copper belt province of Zambia. $\mathbf{J}$ Environ. 2005:1:66-75.

Rao V.S. Principles of weed science. $2^{\text {nd }}$. ed. 2000. 72p.

Rusan M.J.M. Long term effect of wastewater irrigation of forage crops on soil and plant quality parameters. Desalination. 2007;215:143-52. 
Sandalio L.M. et al. Cadmium-induced changes in the growth and oxidative metabolism of pea plants. J Exp Bot. 2001;52:2115-26.

Singh A. Health risk assessment of heavy metals via dietary intake of foodstuffs from the wastewater irrigated site of a dry tropical area of India. Food Chem Toxicol. 2010;48:611-9.

Zhang Y. Effects of long-term sewage irrigation on agricultural soil microbial structural and functional characterizations in Shandong, China. Eur J Soil Biol. 2008:44:84-91. 